\title{
Electro Chemical Recovery of Sodium Hydroxide from Alkaline Salt Solution
}

by

D. T. Hobbs

Westinghouse Savannah River Company

Savannah River Site

Aiken, South Carolina 29808

T. B. Edwards

This paper was prepared in connection with work done under the above contract number with the U.S. Department of Energy. By acceptance of this paper, the publisher and/or recipient acknowledges the U. S. Government's right to retain a nonexclusive, royalty-free license in and to any copyright covering this paper, along with the right to reproduce and to authorize others to reproduce all or part of the copyrighted paper.

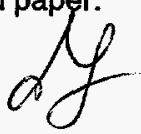




\section{DISCLAIMER}

This report was prepared as an account of work sponsored by an agency of the United States Government. Neither the United States Government nor any agency thereof, nor any of their employees, makes any warranty, express or implied, or assumes any legal liability or responsibility for the accuracy, completeness, or usefulness of any information, apparatus, product, or process disclosed, or represents that its use would not infringe privately owned rights. Reference herein to any specific commercial product, process, or service by trade name, trademark, manufacturer, or otherwise does not necessarily constitute or imply its endorsement, recommendation, or favoring by the United States Government or any agency thereof. The views and opinions of authors expressed herein do not necessarily state or reflect those of the United States Government or any agency thereof.

This report has been reproduced directly from the best available copy.

Available to DOE and DOE contractors from the Office of Scientific and Technical Information, P.O. Box 62, Oak Ridge, TN 37831; prices available from (615) 576-8401.

Available to the public from the National Technical Information Service, U.S. Department of Commerce, 5285 Port Royal Road, Springfield, VA 22161. 


\section{DISCLAIMER}

Portions of this document may be illegible electronic image products. Images are produced from the best available original document. 
WSRC-TR-96-0317

$\begin{array}{ll}\text { Keywords: } & \text { Nitrate, Nitrite, } \\ & \text { Aluminate, Current, } \\ \text { Temperature, } \\ \text { Cathode, Anode } \\ \text { Membrane, Simulant }\end{array}$

Retention Time: permanent

\title{
Electrochemical Recovery of Sodium Hydroxide from Alkaline Salt Solutions (U)
}

\begin{abstract}
DISCLAIMER
This report was prepared as an account of work sponsored by an agency of the United States Government. Neither the United States Government nor any agency thereof, nor any of their employees, makes any warranty, express or implied, or assumes any legal liability or responsibility for the accuracy, completeness, or usefulness of any information, apparatus, product, or process disclosed, or represents that its use would not infringe privately owned rights. Reference herein to any specific commercial product, process, or service by trade name, trademark, manufacturer, or otherwise does not necessarily constitute or imply its endorsement, recommendation, or favoring by the United States Government or any agency thereof. The views and opinions of authors expressed herein do not necessarily state or reflect those of the United States Government or any agency thereof.
\end{abstract}

This report has been reproduced directly from the best available copy.

Available to DOE and DOE contractors from the Office of Scientific and Technical Information, P.O. Box 62, Oak Ridge, TN 37831; prices available from (615) 576-8401.

Available to the public from the National Technical Information Service, U.S. Department of Commerce; 5285 Port Royal Road, Springfield, VA 22161.

Westinghouse Savannah River Company

P.O. Box 616

Aiken, SC 29802

Prepared for the Department of Energy Office of Technology Development, Office of Environmental Management under Contract DE-AC09-88 


\title{
Electrochemical Recovery of Sodium Hydroxide from Alkaline Salt Solutions (U)
}

\author{
by
}

\author{
D. T. Hobbs and T. B. Edwards
}

October, 1996

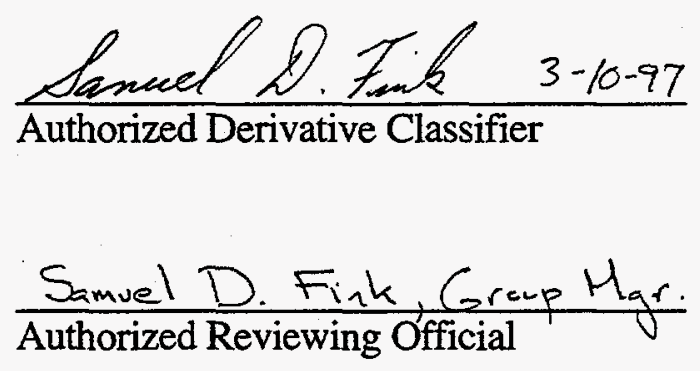

Savannah River Technology Center

Westinghouse Savannah River Company

Aiken, SC 29802

Prepared for the Department of Energy Office of Technology Development, Office of Environmental Management under Contract DE-AC09-88,SR18035 


\section{SUMMARY}

A statistically designed set of tests determined the effects of current density, temperature, and the concentrations of nitrate/nitrite, hydroxide and aluminate on the recovery of sodium as sodium hydroxide (caustic) from solutions simulating those produced from the Savannah River Site (SRS) In-Tank Precipitation process. These tests included low nitrate and nitrite concentrations which would be produced by electrolytic nitrate/nitrite destruction. The tests used a two compartment electrochemical cell with a Nafion ${ }^{\otimes}$ Type 324 ion-exchange membrane. Caustic was successfully recovered from the waste solutions. Evaluation of the testing results indicated that the transport of sodium across the membrane was not significantly affected by any of the varied parameters. The observed variance in the sodium flux is attributed to experimental errors and variations in the performance characteristics of inividual pieces of the organic-based Nafion ${ }^{\circledR}$ membrane. Additional testing is recommended to determine the maximum current density, to evaluate the chemical durability of the organic membrane as a function of current density and to compare the durability and performance characteristics of the organic-based Nafion ${ }^{\circledR}$ membrane with that of other commerically available organic membranes and the inorganic class of membranes under development by Ceramatec ${ }^{\mathscr{\oplus}}$ and PNNL.

\section{INTRODUCTION}

High-level waste (HLW) stored at the Hanford and Savannah River sites contain large amounts of sodium salts that can, in principle, be recovered as sodium hydroxide for recycling. For example, the sodium ions can be separated from the other components in the HLW by electrochemical salt splitting. In the electrochemical salt splitting process, sodium ions migrate across a cation-selective membrane under the influence of an applied electrical potential. In a two compartment cell in which the membrane separates the two electrodes, the HLW waste stream is fed into the anolyte compartment (see Figure 1). Sodium ions migrate across the membrane into the catholyte. Hydroxide is produced at the cathode by the reduction of water. The catholyte product is thus a sodium hydroxide solution. Anionic species such as nitrate, aluminate, and sulfate do not pass through the membrane, and therefore, are retained in the feed stream compartment of the electrochemical cell.

A number of ion-selective membranes have been developed for industrial electrochemical processes including chlorine/caustic production, production of drinking water from brine, and advanced batteries. Organic and inorganic membranes are potential candidates for this application. Organic membranes such as the Nafion ${ }^{\circledR}$ type of membranes have been used in salt splitting applications including the production of sodium hydroxide from sodium sulfate solutions. These membranes exhibit excellent chemical stability over a wide range of $\mathrm{pH}$ values. A statistically designed set of tests were conducted to determine the effects of key operating parameters and variation in the waste composition for the evaluation of the salt splitting process in treating Savannah River Site low-level waste streams[1]. 
Figure 1. Diagram of Electrochemical Salt Splitting Process for the Recovery of Sodium Hydroxide from Alkaline Salt Solutions

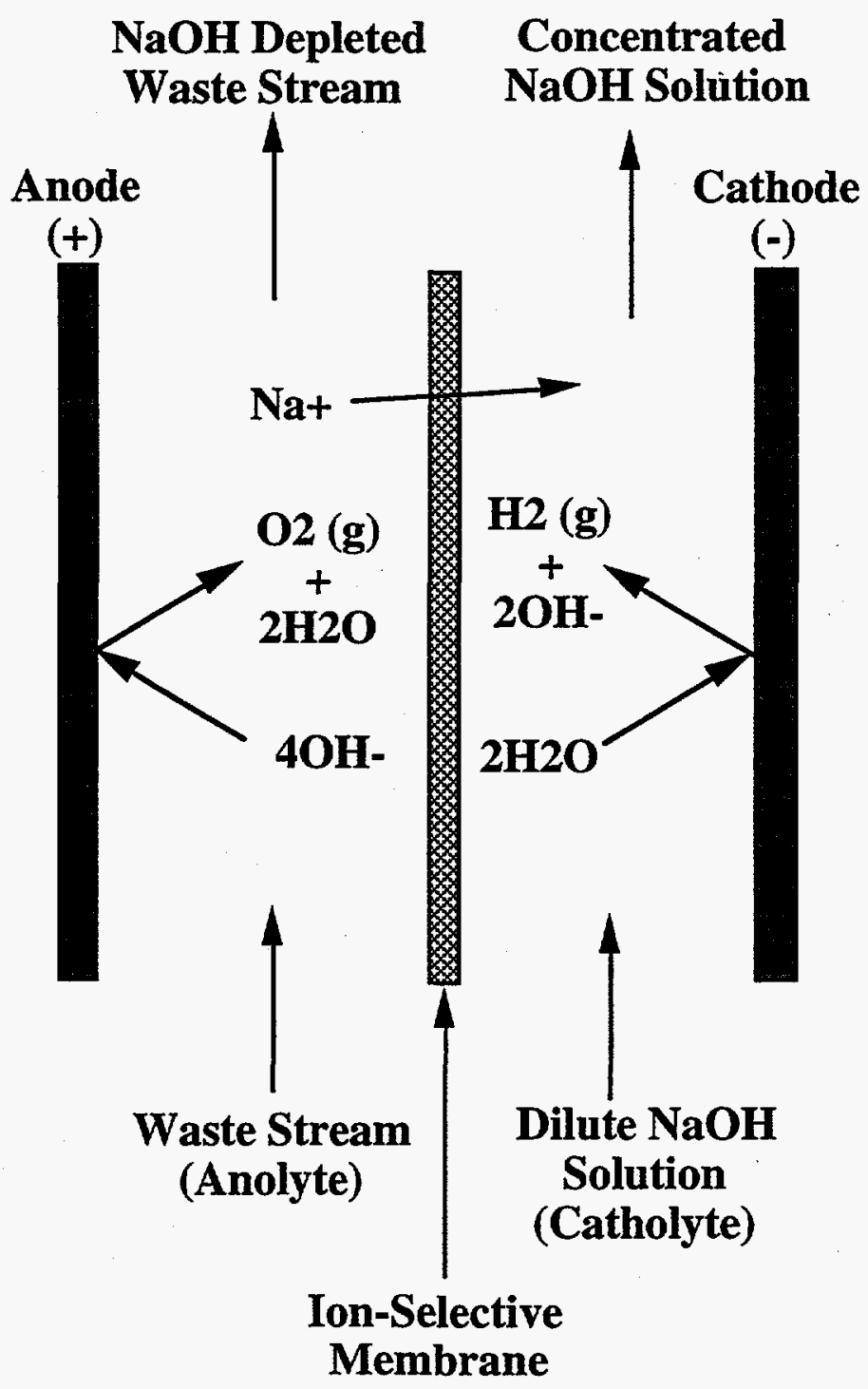

\section{EXPERIMENTAL}

The electrochemical salt splitting tests used a MP electrolyzer manufactured by ElectroCell $\mathrm{AB}$ (Sweden) equipped with a nickel cathode, platinized titanium anode and Nafion ${ }^{\circledR}$ Type 324 membrane. The test equipment included the electrochemical reactor, two rotameters (PVDF shell with EPPM) sealing O-rings, two March model \#AC-3C-MD centrifugal pumps (PVD-lined) and two 2.0 liter polyethylene reservoirs equipped with glass condensers. Electrical power to the cell and the pumps was provided by a BOSS electrochemical controller model \#710 manufactured by the Electrosynthesis Comany (Lancaster, NY).

Temperature was controlled by circulating water through a 0.25 inch $\mathrm{ID}$ stainless steel coil located in each reservoir using a Endocal Refrigerated Circulation Bath, model \#RTE-5. Reservoir temperatures were measured using a thermistor thermometer, Omega model 
\#5831 equipped with thermister probes, Omega model \# OL-703. Current and voltage were recorded from the Boss electrochemical controller readouts. Current was confirmed by measuring the voltage across a shunt using a Fluke model 25 multimeter. Figure 2 provides a schematic diagram of the test equipment. Figure 3 gives photograph of the test equipment.

Reagent grade chemicals and deionized, distilled (DDI) water were used for all salt solution preparations. The initial catholyte solution for all tests was a 1.0 molar sodium hydroxide solution. The anolyte solution was one of eight different salt solutions having the composition indicated in Table $\mathrm{I}$.

Table I. Initial Composition of Anolyte Salt Solutions*

Concentration (molar)

\begin{tabular}{cllll} 
Solution ID & $\mathrm{NaNO}_{3}$ & $\mathrm{NaNO}_{2}$ & $\mathrm{NaOH}$ & $\mathrm{NaAlO}_{2}$ \\
\hline 000 & 1.19 & 0.365 & 2.05 & 0.255 \\
+++ & 2.29 & 0.706 & 3.50 & 0.500 \\
+++ & 0.0765 & 0.0235 & 3.50 & 0.500 \\
+-- & 2.29 & 0.706 & 0.60 & 0.010 \\
-+- & 0.0765 & 0.0235 & 3.50 & 0.010 \\
+-+ & 2.29 & 0.706 & 0.60 & 0.500 \\
-+ & 0.0765 & 0.0235 & 0.60 & 0.500 \\
+-- & 2.29 & 0.706 & 0.60 & 0.010 \\
--- & 0.0765 & 0.0235 & 0.60 & 0.010
\end{tabular}

*All solutions contained the following salts (concentrations): sodium carbonate $(0.16 \mathrm{M})$, sodium silicate $(0.0038 \mathrm{M})$, sodium phosphate $(0.0085 \mathrm{M})$, sodium chloride $(0.022 \mathrm{M})$, sodium fluoride $(0.015 \mathrm{M})$ and sodium chromate $(0.0033 \mathrm{M})$.

The following experimental procedure was used for each test. The electrochemical cell was assembled and installed in the testing system. Prior to the first usage and between each test, each piece of Nafion ${ }^{\circledR}$ membrane was heated for 1 hour at $80^{\circ} \mathrm{C}$ in a diluted sulfuric acid solution, rinsed with DDI water, and then allowed to stand in DDI prior to initial use.

Between tests, the membrane was allowed to stand in a $1.0 \mathrm{M}$ sodium hydroxide solution. The catholyte reservoir was charged with $1.5 \mathrm{~L}$ of a $1.0 \mathrm{M}$ sodium hydroxide solution and the anolyte reservoir charged with $1.5 \mathrm{~L}$ of the simulated waste solution. The centrifugal pumps and the refrigerated bath were turned on, the solutions circulated through the system and heated to the desired temperature. After reaching the test temperature, the DC power supply in the BOSS electrochemical controller was activated and current supplied to the cell at the desired current density.

The temperature of the refrigerated bath liquid was adjusted to maintain the temperature of the solutions in each reservoir to within $\pm 2{ }^{\circ} \mathrm{C}$. Voltage, current, temperature, flowrate, solution volumes and charge were recorded periodically during each test. Liquid samples from each reservoir were taken periodically during each test. A test was stopped after 6 hours, when solids were observed in the anolyte or when a large increase in the cell voltage occurred. After shutting off the power supply, the anolyte and catholyte were allowed to 
cool to room temperature. Both reservoirs were drained and sampled for analysis. The DDI water was introduced and circulated through the cell to flush out each compartment. The rinse solutions were discarded and cell disassembled for inspection. After inspection, the cell components were rinsed and stored until reassembled for the next test.

Liquid samples were analyzed for sodium, aluminum, chromium, silicon and phosphorus by atomic absorption spectroscopy (AAS). Free hydroxide, aluminate and carbonate were determined titrimetrically. Nitrate, nitrite, sulfate, phosphate, fluoride and chloride were determined by ion chromatography (IC).

Figure 2. Schematic Diagram of Electrochemical Caustic Recovery Bench-Scale Test Equipment

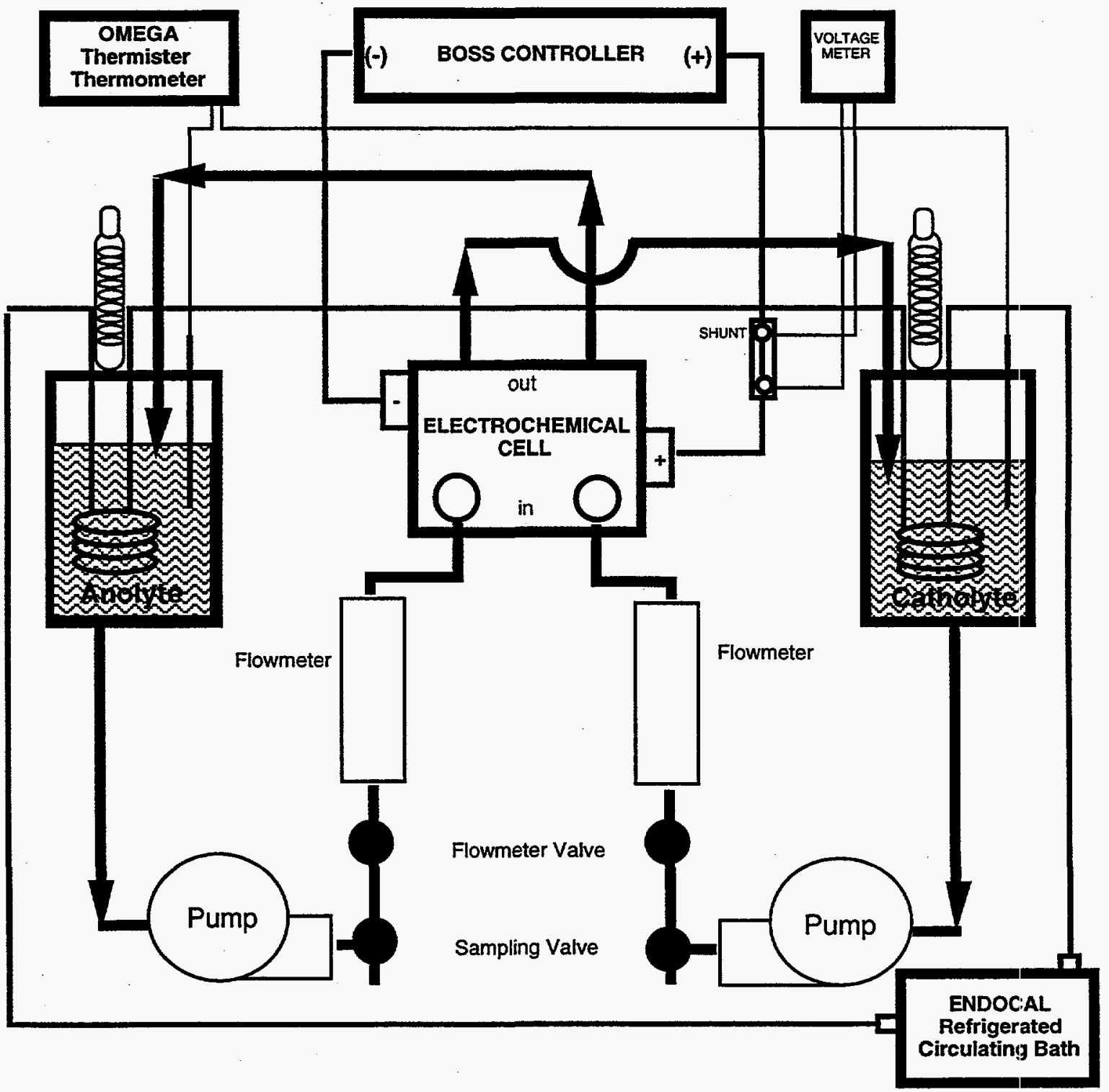


Figure 3. Photograph of Electrochemical Caustic Recovery Bench-Scale Test Equipment

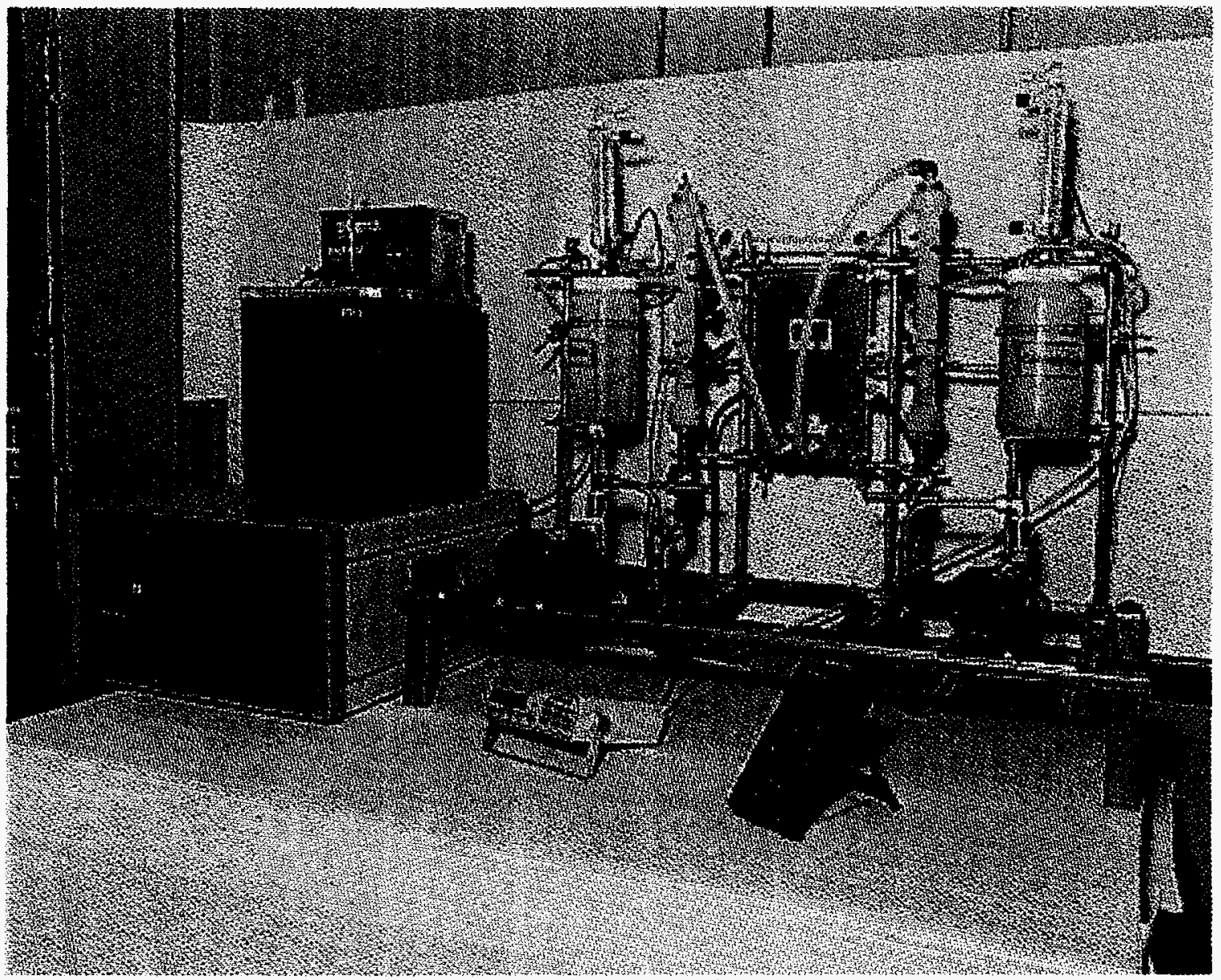




\section{RESULTS AND DISCUSSION}

A fractional factorial design was used to evaluate the effects of current density, temperature and the concentrations of nitrate/nitrite, hydroxide and aluminate on the recovery of sodium hydroxide from simulated waste solutions. To reduce the size of the design matrix, the concentrations of nitrate and nitrite were kept a fixed ratio of 3.26:1. Nitrate/nitrite and hydroxide concentrations were varied to reflect feed solutions with and without nitrate/nitrite destruction prior to caustic recovery. A total of four center point tests were conducted, two at the start and two at the conclusion, to evaluate the experimental variablility. Minimum, center point and maximum values for the five test parameters are provided in Table II.

Table II. Range of Parameter Values in Test Matrix

Temperature $\left({ }^{\circ} \mathrm{C}\right)$

Current Density $\left(\mathrm{amp} / \mathrm{m}^{2}\right)$

Total $\mathrm{NO}_{3}^{-} \& \mathrm{NO}_{2}^{-}$Conc. (M)

$\mathrm{OH}^{-}$Concentration (M)

$\mathrm{AlO}_{2}^{-}$Concentration (M)

Minimum (-)

30

1000

0.100

0.600

0.010
Center Point (0)

50

2500

1.56

2.05

0.255
Maximum (+)

70

4000

3.00

3.50

0.500

Table III provides the test ID, run order and parameter key for the 12 experiments. An uncontrolled variable that developed during the course of the testing was the use of three different pieces of membrane. Single pieces of membrane were used for tests CR3 through CR9, CR10 and CR11 through CR14. All three pieces of membrane were cut from a single larger piece of membrane. Pretreatment and storage were identical for all pieces of the membrane.

Originally CR11 was to be run immediately after CR10. However, during the setup prior to turning on the power supply, a leak in the membrane developed resulting in the mixing of the anolyte and catholyte solutions. There was no visible signs of a hole or tear in the membrane and, therefore, the leak was attributed to improper assembly of the cell. A new piece of membrane was inserted into the cell and the next test, CR12, performed. Test CR11 was performed after preparing fresh salt solution. 


\section{Table III. Matrix Test Run Order, ID and Conditions}

\begin{tabular}{cccccccc}
$\begin{array}{c}\text { Run } \\
\text { Order }\end{array}$ & Test ID & $\begin{array}{c}\text { FFDesign } \\
\text { Row No. }\end{array}$ & $\begin{array}{c}\mathrm{NO}_{3}^{-}+\mathrm{NO}_{2}^{-} \\
\text {Conc. }\end{array}$ & $\begin{array}{c}\mathrm{OH}^{-} \\
\text {Conc. }\end{array}$ & $\begin{array}{c}\text { Temp. } \\
\text { Current }\end{array}$ & $\begin{array}{c}\mathrm{AlO2} \\
\text { Density }\end{array}$ & \begin{tabular}{c} 
Conc \\
\hline 1
\end{tabular} \\
\hline CR3 & 1 & 0 & 0 & 0 & 0 & 0 \\
2 & CR4 & 2 & 0 & 0 & 0 & 0 & 0 \\
3 & CR5 & 5 & + & + & + & + & + \\
4 & CR6 & 10 & - & + & + & - & + \\
5 & CR7 & 3 & + & - & + & - & - \\
6 & CR8 & 4 & - & + & - & + & - \\
7 & CR9 & 6 & + & - & - & + & + \\
8 & CR10* & 7 & - & - & - & - & + \\
9 & CR12* & 9 & + & + & - & - & - \\
10 & CR11 & 8 & - & - & + & + & - \\
11 & CR13 & 11 & 0 & 0 & 0 & 0 & 0 \\
12 & CR14 & 12 & 0 & 0 & 0 & 0 & 0
\end{tabular}

*new sheet of membrane installed in electrochemical cell

The changes in moles of sodium ion and hydroxide in the catholyte and anolyte with total charge passed were determined for each test. Plots of moles of sodium and hdyroxide versus charge passed are provided in Figures 4-15. Transport of sodium and hydroxide out of the anolyte is a loss and, therefore, has a negative sign. Transport of sodium and hydroxide into the catholyte is a gain and, therefore, has a positive sign. In theory, the moles of sodium transferred out of the anolyte should equal that into the catholyte, and assuming $100 \%$ electrical efficiency, the absolute value of the flux is $1.04 \mathrm{E}-05$ mole/coulomb of charge.

The sodium ion and hydroxide fluxes (moles/coulomb) were determined as the slope of the linear fit of the data from a plot of the total moles of sodium or hydroxide in the respective compartments versus the charge passed (see Figures 4 - 15). Table IV presents a summary of the fluxes for each compartment in the test matrix.

Table $V$ presents a summary of the electrical efficiency for each test determined from the flux data reported in Table IV. The electrical efficiency (\%) is determined by dividing the sodium or hydroxide flux by the theoretical flux $( \pm 1.04 \mathrm{E}-05$ mole/coulomb) and multiplying the result by 100 .

$$
\begin{aligned}
\text { Electrical Efficiency }(\%) & =\left(\mathrm{F}_{\mathrm{m}} / \mathrm{F}_{\mathrm{t}}\right)^{* 100} \\
\text { where } \mathrm{F}_{\mathrm{m}} & =\text { measured sodium or hydroxide flux (mole/coulomb), } \\
\mathrm{F}_{\mathrm{t}} & =\text { theoretical sodium or hydroxide flux (mole/coulomb). }
\end{aligned}
$$


Table IV. Sodium Ion and Hydroxide Fluxes in Catholyte and Anolyte Solutions

\begin{tabular}{llllll} 
& \multicolumn{2}{c}{ Catholyte } & \multicolumn{2}{c}{ Anolyte } \\
Test ID & Sodium & Hydroxide & Sodium & Hydroxide \\
CR3 & $1.10 \mathrm{E}-05$ & $9.89 \mathrm{E}-06$ & $-1.24 \mathrm{E}-05$ & $-1.05 \mathrm{E}-05$ \\
CR4 & $9.98 \mathrm{E}-06$ & $1.06 \mathrm{E}-05$ & $-1.12 \mathrm{E}-05$ & $-8.80 \mathrm{E}-06$ \\
CR5 & $9.95 \mathrm{E}-06$ & $8.24 \mathrm{E}-06$ & $-1.13 \mathrm{E}-05$ & $-8.25 \mathrm{E}-06$ \\
CR6 & $7.80 \mathrm{E}-06$ & $8.13 \mathrm{E}-06$ & $-1.88 \mathrm{E}-05$ & $-1.17 \mathrm{E}-05$ \\
CR7 & $1.05 \mathrm{E}-05$ & $8.37 \mathrm{E}-06$ & $-1.49 \mathrm{E}-05$ & $-6.57 \mathrm{E}-06$ \\
CR8 & $9.86 \mathrm{E}-06$ & $6.85 \mathrm{E}-06$ & $-6.08 \mathrm{E}-06$ & $-9.63 \mathrm{E}-06$ \\
CR9 & $1.07 \mathrm{E}-05$ & $7.07 \mathrm{E}-06$ & $-1.20 \mathrm{E}-05$ & $-6.83 \mathrm{E}-06$ \\
CR10 & $7.49 \mathrm{E}-06$ & $7.76 \mathrm{E}-06$ & $-1.02 \mathrm{E}-05$ & $-9.33 \mathrm{E}-06$ \\
CR12 & $8.67 \mathrm{E}-06$ & $1.15 \mathrm{E}-05$ & $-1.57 \mathrm{E}-05$ & $-1.61 \mathrm{E}-05$ \\
CR11 & $7.43 \mathrm{E}-06$ & $4.36 \mathrm{E}-06$ & $-9.07 \mathrm{E}-06$ & $-6.08 \mathrm{E}-06$ \\
CR13 & $7.43 \mathrm{E}-06$ & $5.84 \mathrm{E}-06$ & $-8.70 \mathrm{E}-06$ & $-7.92 \mathrm{E}-06$ \\
CR14 & $6.38 \mathrm{E}-06$ & $6.63 \mathrm{E}-06$ & $-8.52 \mathrm{E}-06$ & $-6.01 \mathrm{E}-06$
\end{tabular}

Analysis of the sodium and hydroxide flux data indicated that none of the varied pararneters were statistically significant in affecting the transport of sodium from the anolyte into the catholyte. That is, the transport of sodium across the Nafion ${ }^{\circledR}$ membrane was not affected over the range of salt solution compositions, current densities $\left(1000-4000 \mathrm{amp} / \mathrm{m}^{2}\right)$ and temperatures $\left(30-70^{\circ} \mathrm{C}\right)$ tested. There is considerable spread in the data attributed to experimental errors associated with sampling and analytical measurements as well as the performance characteristics of different pieces of membrane. 
Table V. Electrical Efficiencies for Transport of Sodium and Hydroxide

Test ID

CR3

CR4

CR5

CR6

CR7

CR8

CR9

CR10

CR12

CR11

CR13

CR14

Catholyte
Sodium $\quad$ Hydroxide

106

96.0

95.7

75.0

101

94.8

103

72.0

83.4

71.4

71.4

61.3
95.1

102

79.2

78.1

80.5

65.9

68.0

74.6

111

41.9

56.2

63.7 Anolyte

Sodium

Hydroxide

119

101

108

84.6

109

79.3

181

112

143

63.2

58.5

92.6

115

65.7

98.1

89.7

151

155

87.2

58.5

83.7

76.2

81.9

57.8

Table VI lists the current density, temperature cell voltage and whether precipitation of solids occurred during a test. There was no evidence that exposure of the membrane to the higher cell voltages for short periods of time significantly affect the transport characteristics of the membrane. However, the membrane vendor recommends removal of solids in feed streams to membrane cell to minimize the possibility of fouling or physical attack of the membrane by the solids.

The increase in the cell voltage is attributed to the depletion of hydroxide and nitrite in the anolyte solution. Upon depletion of these species, the anodic reactions switch from that of hydroxide and nitrite oxidation to water oxidation. The standard potential for water oxidation is -1.229 volts compared to -0.401 volts for hydroxide and -0.01 volts for nitrite[2]. Thus, for the cell to continue to operate at the same current density, the potential must increase.

Upon depletion of the hydroxide in the anolyte, aluminum and silicon will precipate as hydrous oxides. Typically, alumina and silica precipitate when the $\mathrm{pH}$ falls below 12 (hydroxide concentration of 0.01 molar). The quantity of solids will depend on the concentration of aluminum, silicon and the hydroxide. Although solids were produced during most of the tests, there was no visible signs of attack or fouling of the membrane as a result of the solids formation. 
Table VI. Test Conditions and Selected Findings of Matrix Tests

\begin{tabular}{|c|c|c|c|c|}
\hline Test ID & $\begin{array}{l}\text { Temp. } \\
\left({ }^{\circ} \mathrm{C}\right)\end{array}$ & $\begin{array}{l}\text { Current Density } \\
\left(\mathrm{amp} / \mathrm{m}^{2}\right)\end{array}$ & $\begin{array}{l}\text { Cell Voltage* } \\
\text { (V) }\end{array}$ & $\begin{array}{l}\text { Solids } \\
\text { Formation ** }\end{array}$ \\
\hline CR3 & & 2500 & $5.7-6.0,7.4$ & yes \\
\hline CR4 & 50 & 2500 & $5.5-6.0,8.4$ & no \\
\hline CR5 & 70 & 4000 & $6.4-6.5,8.1$ & yes \\
\hline CR6 & 70 & 1000 & $3.2-3.3,3.3$ & no \\
\hline CR7 & 70 & 1000 & $3.3-3.7,3.7$ & trace \\
\hline CR8 & 30 & 4000 & $7.9-8.2,9.4$ & no \\
\hline CR9 & 30 & 4000 & $9.2-10.1,9.6$ & yes \\
\hline CR10 & 30 & 1000 & $4.5-5.0,5.8$ & yes \\
\hline CR12 & 30 & 1000 & $3.8-4.0,4.0$ & no \\
\hline CR11 & 70 & 4000 & $7.1-10.2,10.2$ & yes \\
\hline CR13 & 50 & 2500 & $5.4-5.8,7.8$ & yes \\
\hline CR14 & 50 & 2500 & $5.4-5.7,6.4$ & yes \\
\hline \multicolumn{5}{|c|}{$\begin{array}{l}\text { * The first values are the range of cell voltages during test until latter stage } \\
\text { when sharp rise in potential was observed; the latter value is the potential at } \\
\text { the conclusion of the test. }\end{array}$} \\
\hline
\end{tabular}

Analysis of the anolyte samples for nitrate and nitrite content indicated that during a test, nitrite is oxidized to nitrate. Since this reaction competes with the predominant reaction, hydroxide oxidation, additional sodium hydroxide can be recovered without exhausting available hydroxide resulting in precipitation of alumina and silica. After caustic removal, the anolyte solution is a more corrosive solution due to the depletion of hydroxide and nitrite.

The catholyte samples were also analyzed for the other components the anolyte compartment. Since the majority of these components are anionic, transport accross the Nafion ${ }^{\circledR}$ membrane should be very small. This information is important, however, to determine the chemical purity of the recovered caustic. The flux of these species into the catholyte was very small. Appendix I provides a table of the fluxes for each component. The fluxes were determined by dividing the product of the final measured concentrations and the final catholyte volume by the total charge passed (equation 1).

$$
\begin{aligned}
\text { Flux (mole/coulomb) }=\left(\mathrm{C}_{\mathrm{f}}^{\mathrm{j}} \times \mathrm{V}_{\mathrm{f}}\right) / \mathrm{Q}_{\mathrm{t}} & \\
\text { where } \mathrm{C}_{\mathrm{f}}^{\mathrm{j}} & =\text { final concentration (mole/L) of } \mathrm{j} \text { species } \\
\mathrm{V}_{\mathrm{f}} & =\text { final catholyte volume }(\mathrm{L}) \\
\text { and } \quad \mathrm{Q}_{\mathrm{t}} & =\text { total charge (coulombs) passed during experiment }
\end{aligned}
$$

In general, the fluxes of the anionic species were 10000 times or more lower than that measured for sodium. Exceptions to this were carbonate and nitrate and aluminum at high 
salt concentrations, where the fluxes were approximately 100 to 1000 times lower than that for sodium. The high carbonate flux is attributed to the transport of carbonate across the membrane and adsorption of atmospheric carbon dioxide which reacts with hydroxide to produce carbonate. No attempt was made during the test to prevent the exposure of the catholyte solution to air. The relatively high aluminum flux may be result of the presence of cationic aluminum species $\left(\mathrm{Al}^{3+}, \mathrm{Al}(\mathrm{OH})^{2+}\right.$ and $\mathrm{Al}(\mathrm{OH})_{2}^{+}$) in equilibrium with $\mathrm{Al}(\mathrm{OH})_{4}^{-}$ in the strongly alkaline solution.

\section{CONCLUSIONS AND RECOMMENDATIONS}

A statistically designed set of tests determined the effects of current density, temperature, and the concentrations of nitrate/nitrite, hydroxide and aluminate on the recovery of sodium as sodium hydroxide (caustic) from solutions simulating those produced from the Savannah River Site (SRS) In-Tank Precipitation process. These tests included low nitrate and nitrite concentrations which would be produced by electrolytic nitrate/nitrite destruction. Evaluation of the testing results indicated that the transport of sodium across the membrane was not significantly affected by any of the varied parameters. The observed variance in the sodium flux is attributed to experimental errors and variations in the performance characteristics of inividual pieces of membrane. It is recommended that the process be designed to maintain a high $\mathrm{pH}(>12)$ to ensure that alumina and silica do not precipitate. Additional testing is recommended to determine the maximum current density, to evaluate the chemical durability of the organic membrane as a function of current density and to compare the durability and performance characteristics of the organic based Nafion ${ }^{3}$ membrane with that of other commerically available organic membranes and the inorganic class of membranes under development by Ceramatec ${ }^{\oplus}$ and PNNL.

\section{ACKNOWLEDGEMENTS}

The author wishes to acknowledge the contributions of Lin Thacker in the fabrication and operation of the testing equipment and technical discussions involving this work with Dean Kurath (PNNL), Eric Rudd and Marilyn Warrant (Eltech Research Corporation) and David Genders (Electrosynthesis Company, Inc.). This work was funded by the Office of Science and Tehnology, Office of Environmental Management through the Tank Focus Area Program, D. W. Geiser, Headquarters Focus Area Team Lead, and W. C. Laveille, Technical Program Officer.

\section{REFERENCES}

1.D. T. Hobbs, Technical Task Plan SR1-6-WT-41, Subtask 2 - "Caustic Recovery and Recycle," revision 3, April 8, 1996.

2. R. C. Weast, editor, Hanbook of Chemistry and Physics, 65th edition, CRC Press, Boca Raton, FL, 1984. 
Figure 4. Change in Moles of Sodium and Hydroxide in Catholyte and Anolyte for Test CR3

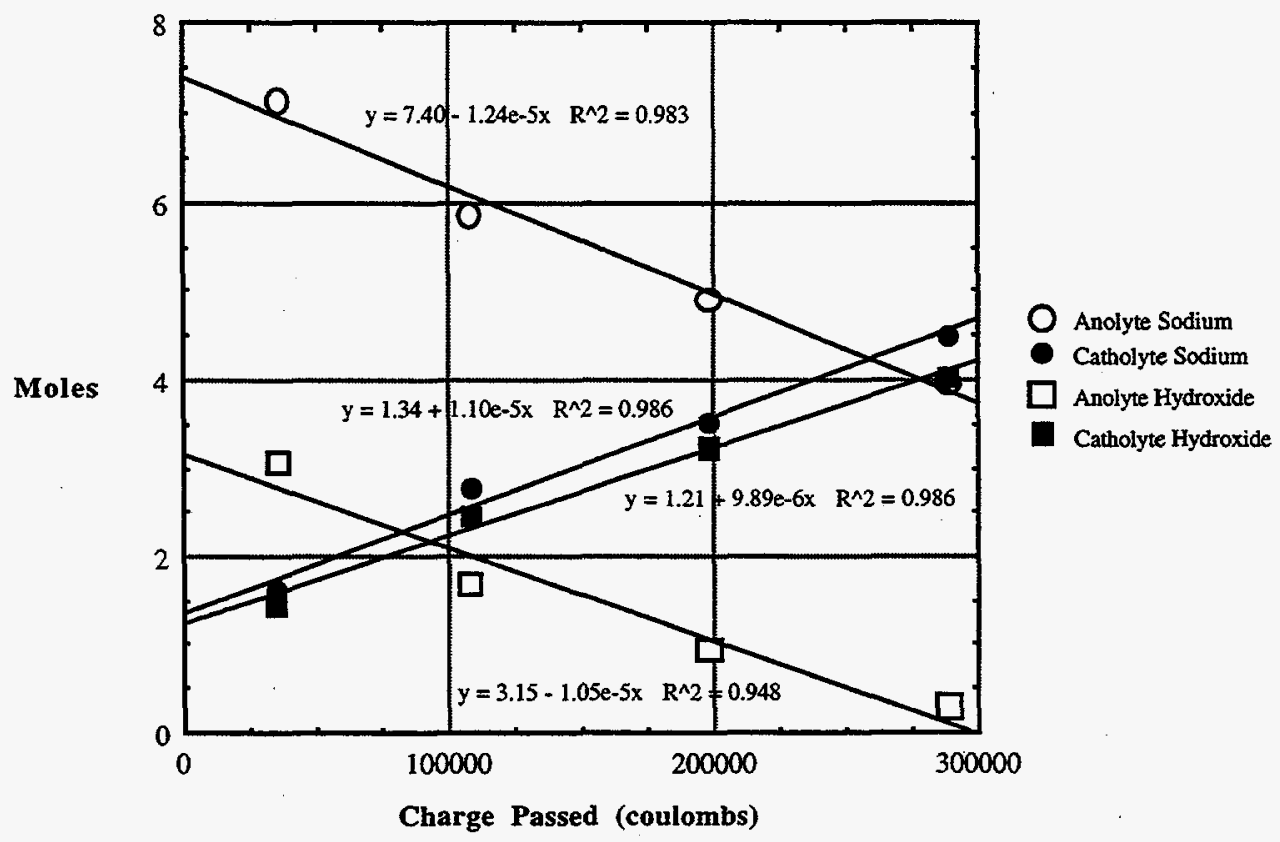

Figure 5. Change in Moles of Sodium and Hydroxide in Catholyte and Anolyte for Test CR4

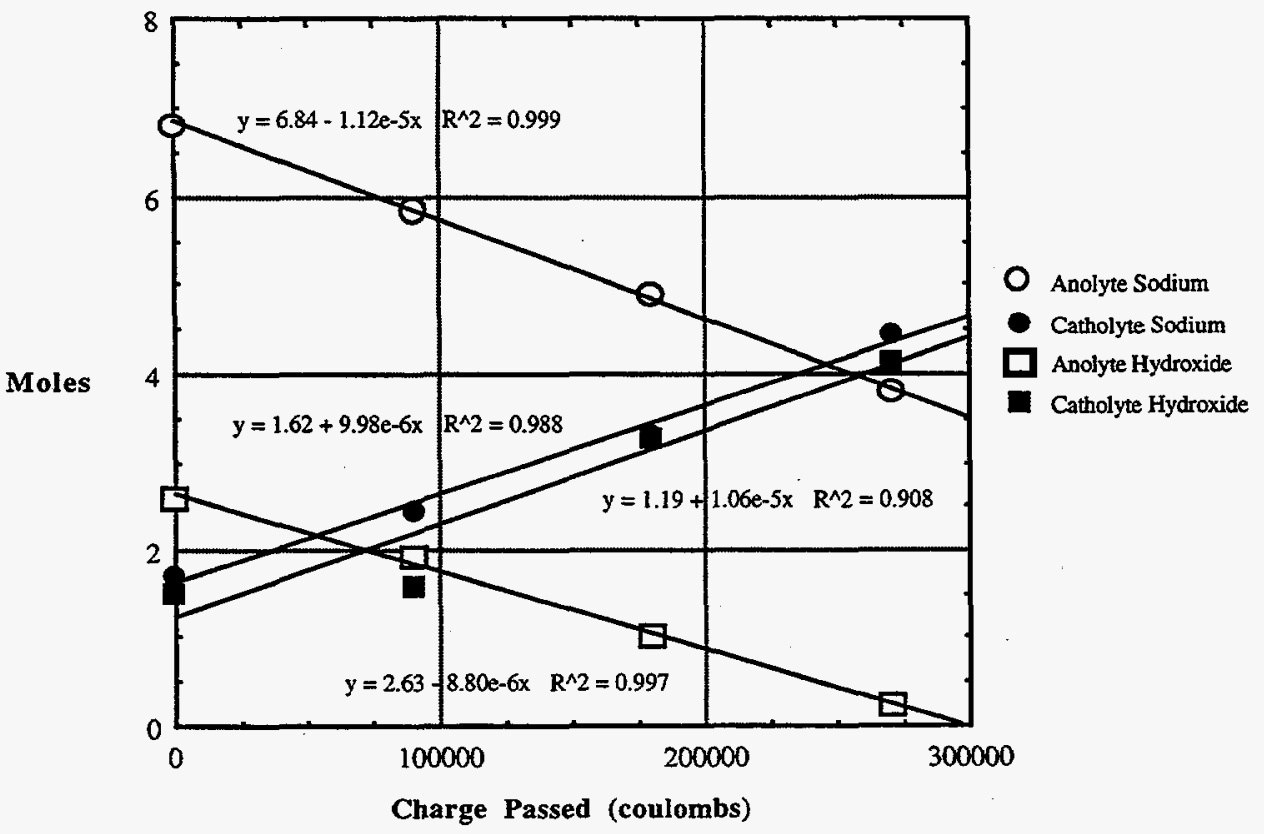


Figure 6. Change in Moles of Sodium and Hydroxide in Catholyte and Anolyte for Test CR5

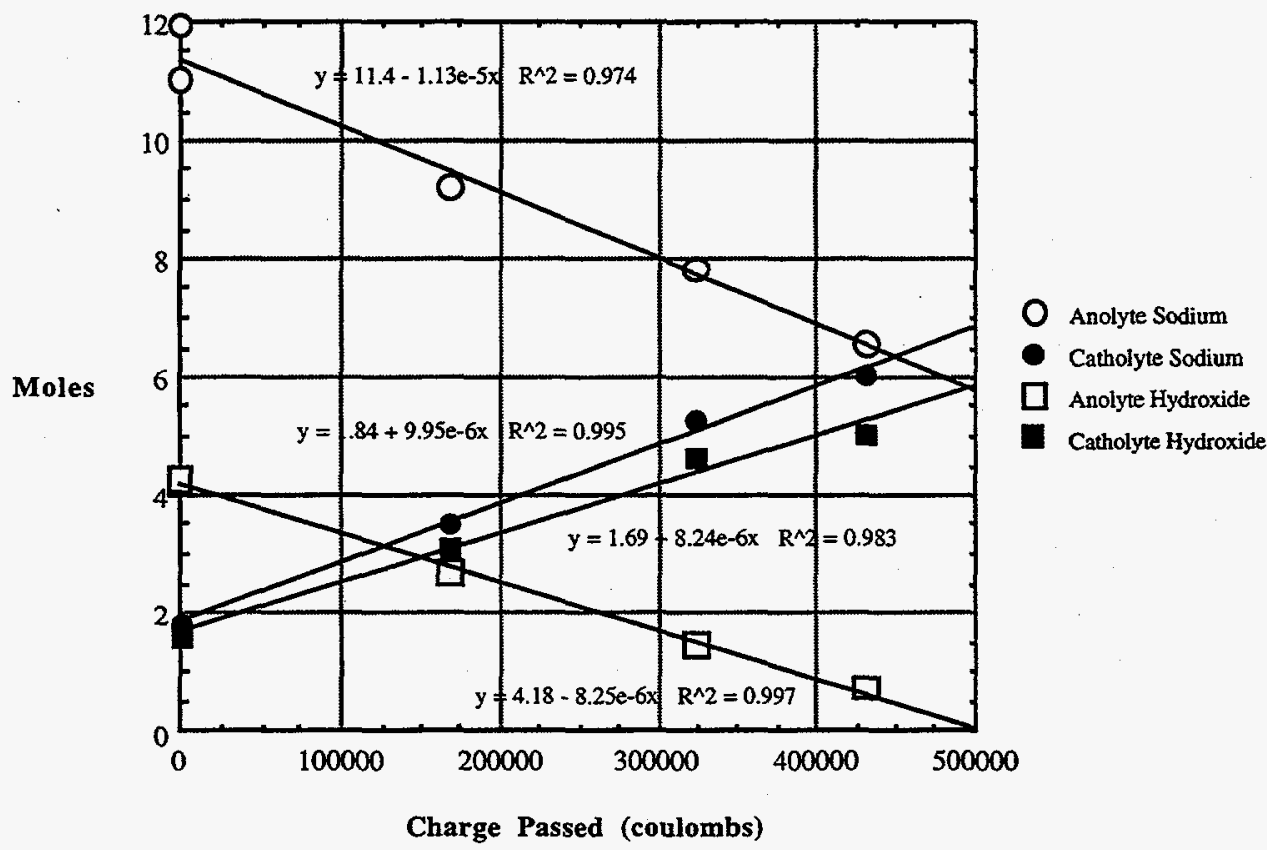

Figure 7. Change in Moles of Sodium and Hydroxide in Catholyte and Anolyte for Test CR6

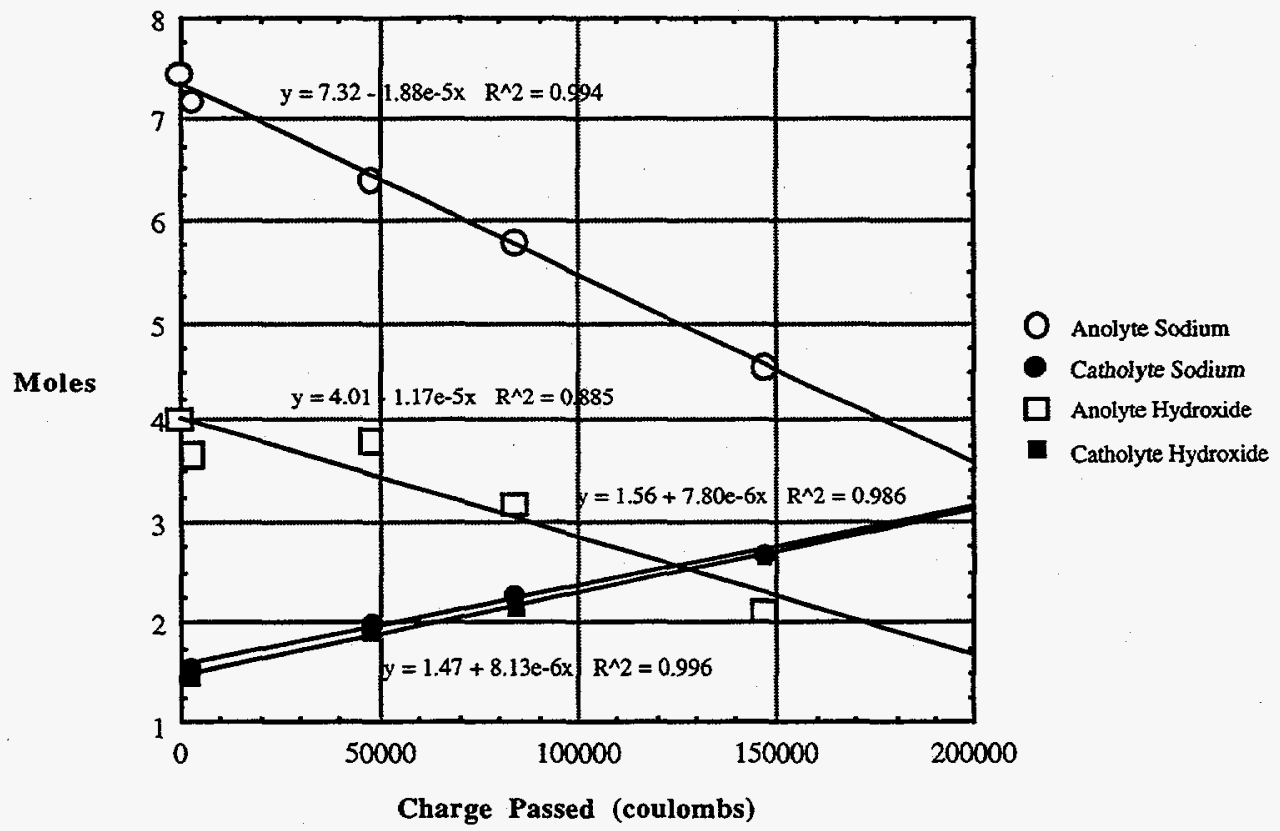


Figure 8. Change in Moles of Sodium and Hydroxide in Catholyte and Anolyte for Test CR7

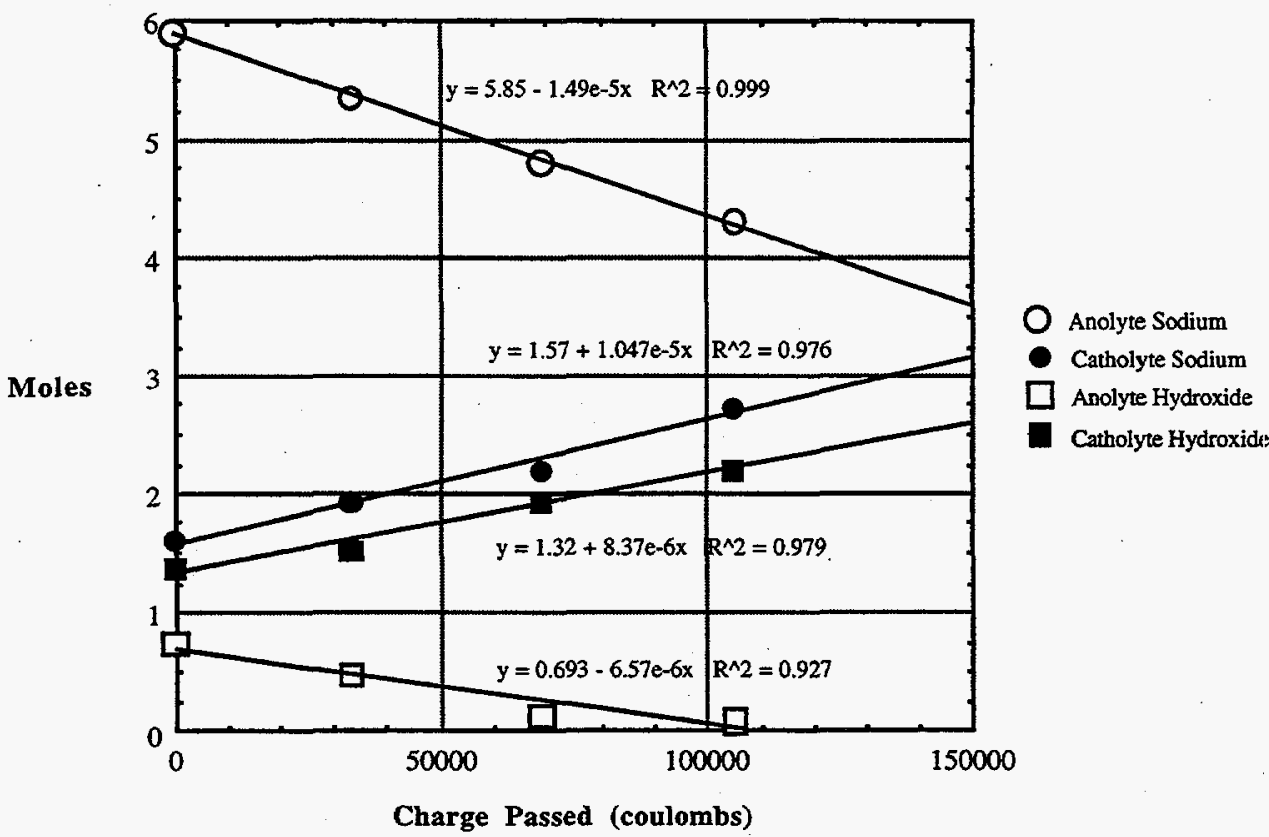

Figure 9. Change in Moles of Sodium and Hydroxide in Catholyte and Anolyte for Test CR8

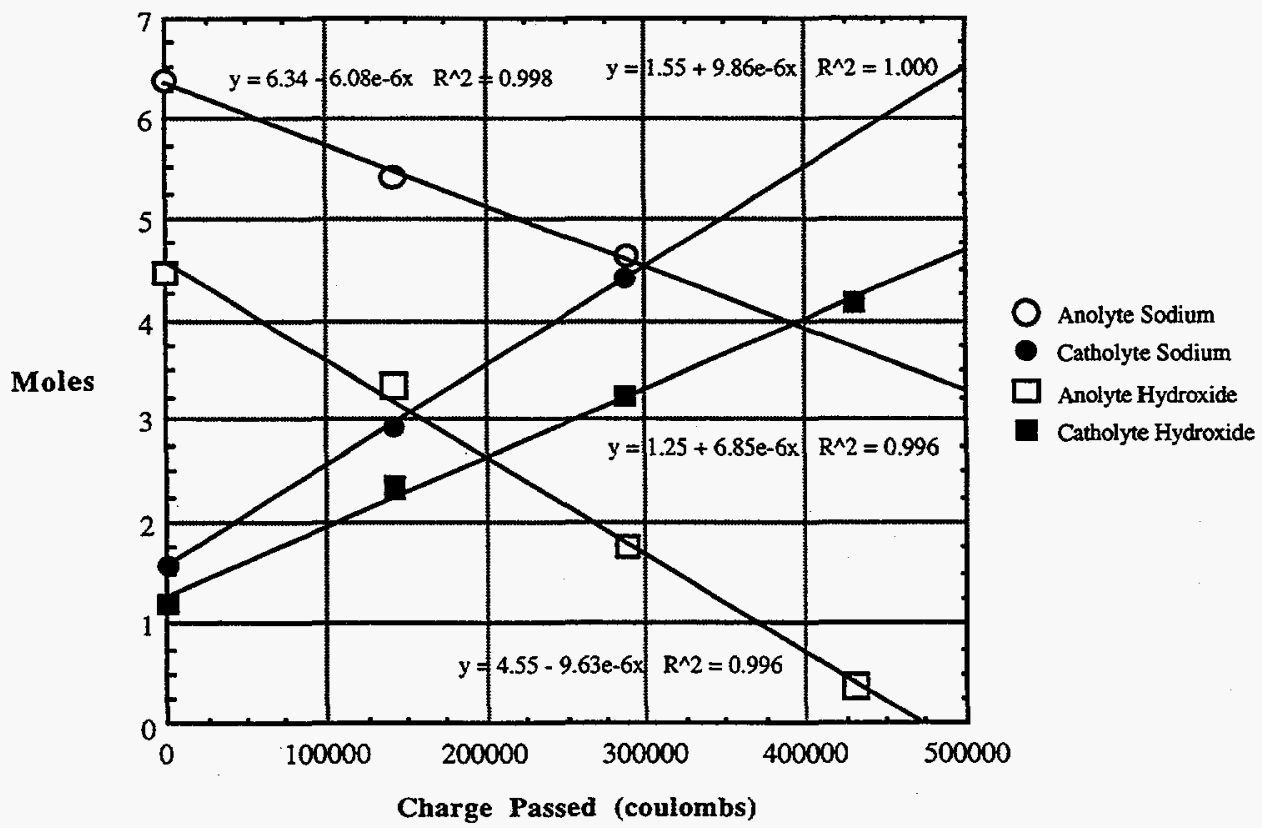


Figure 10. Change in Moles of Sodium and Hydroxide in Catholyte and Anolyte for Test CR9

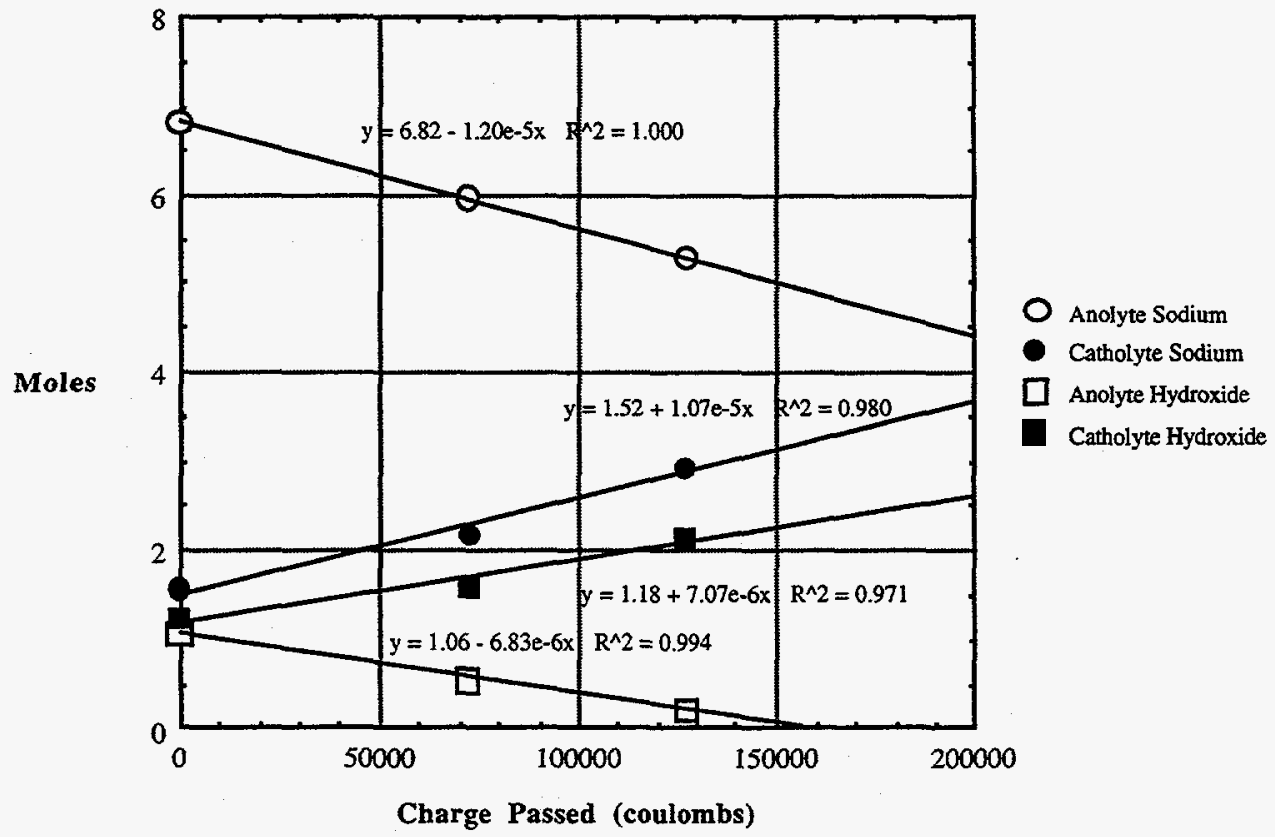

Figure 11. Change in Moles of Sodium and Hydroxide in Catholyte and Anolyte for Test CR10

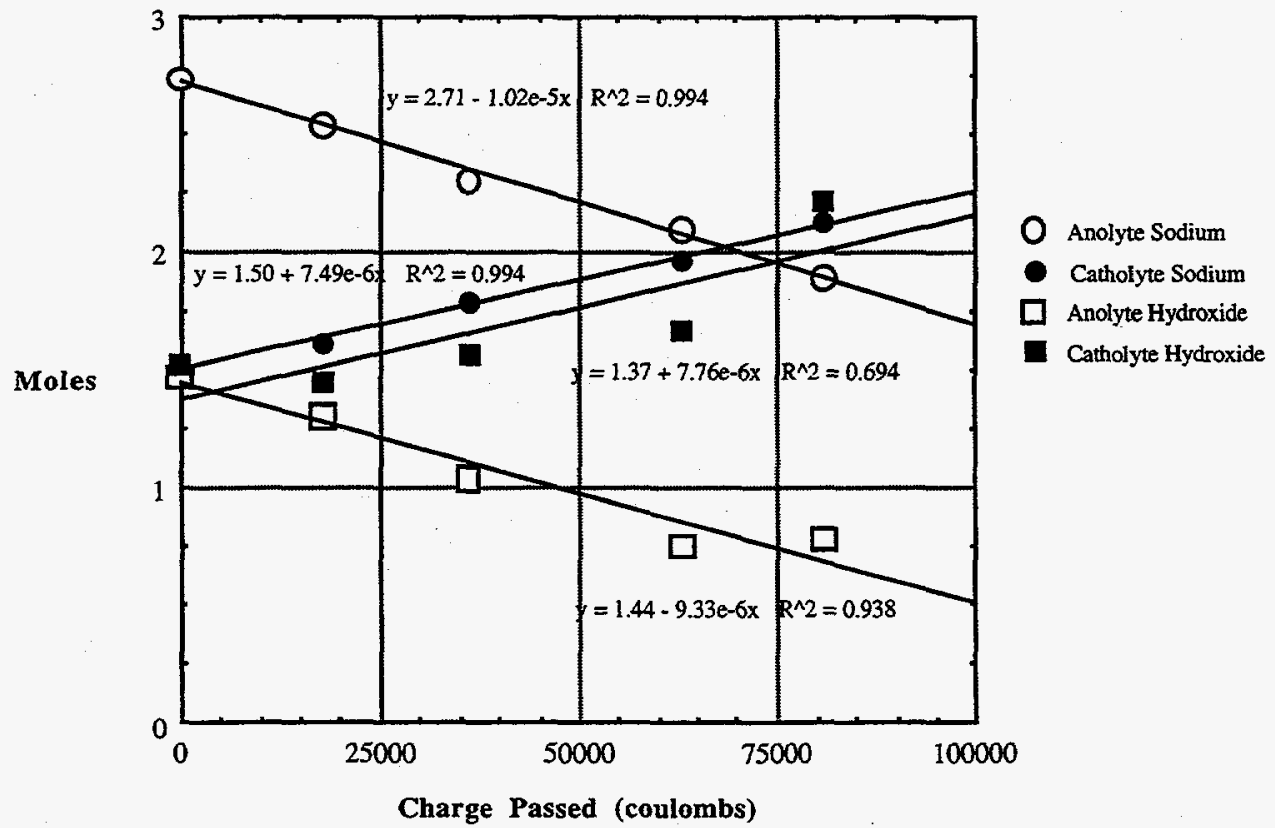


Figure 12. Change in Moles of Sodium and Hydroxide in Catholyte and Anolyte for Test CR11

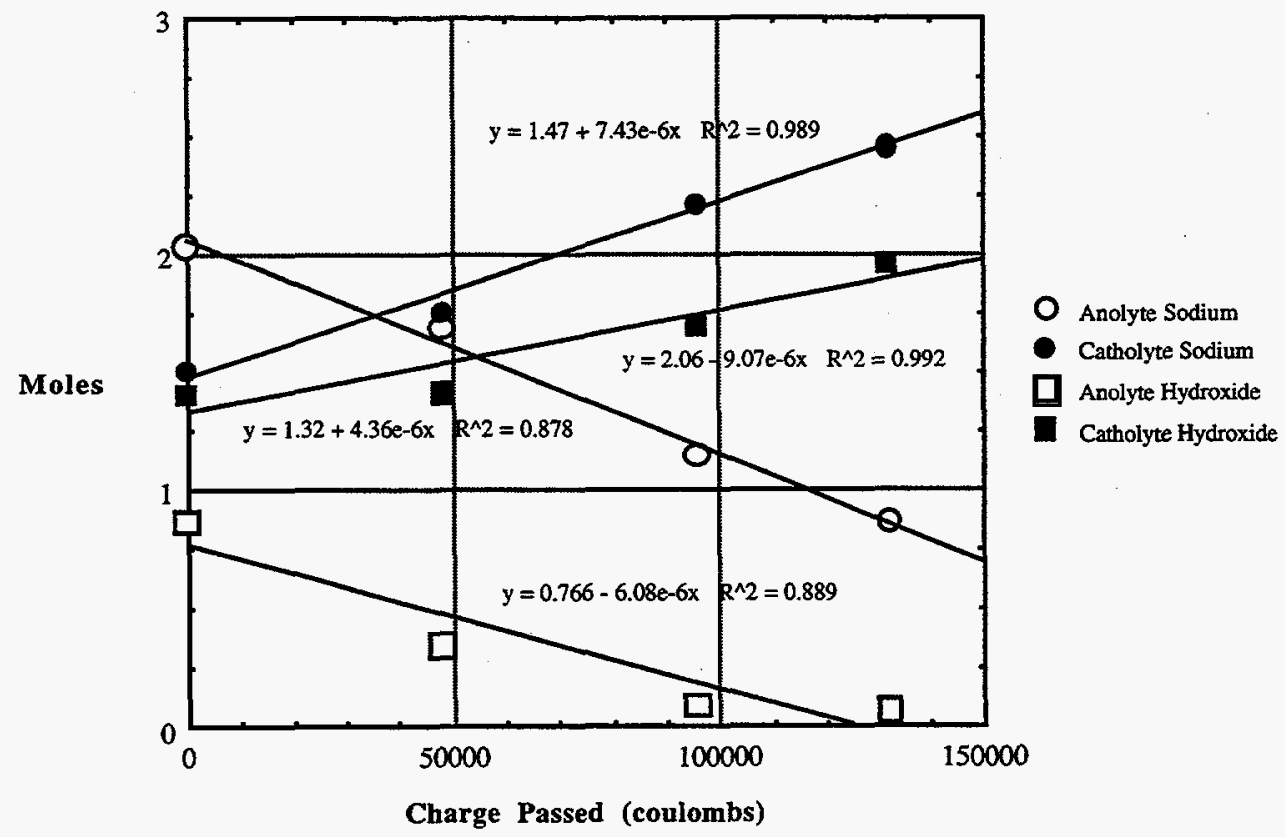

Figure 13. Change in Moles of Sodium and Hydroxide in Catholyte and Anolyte for Test CR12

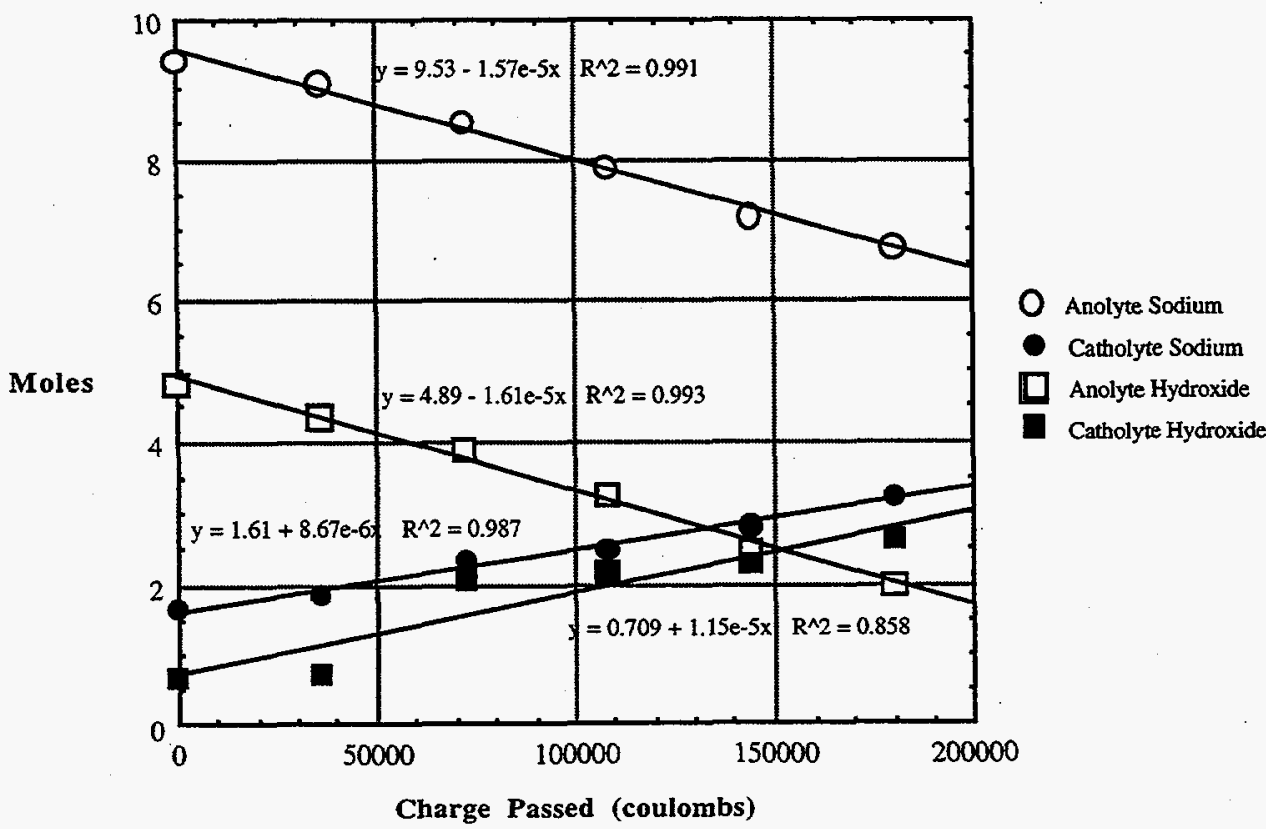


Figure 14. Change in Moles of Sodium and Hydroxide in Catholyte and Anolyte for Test CR13

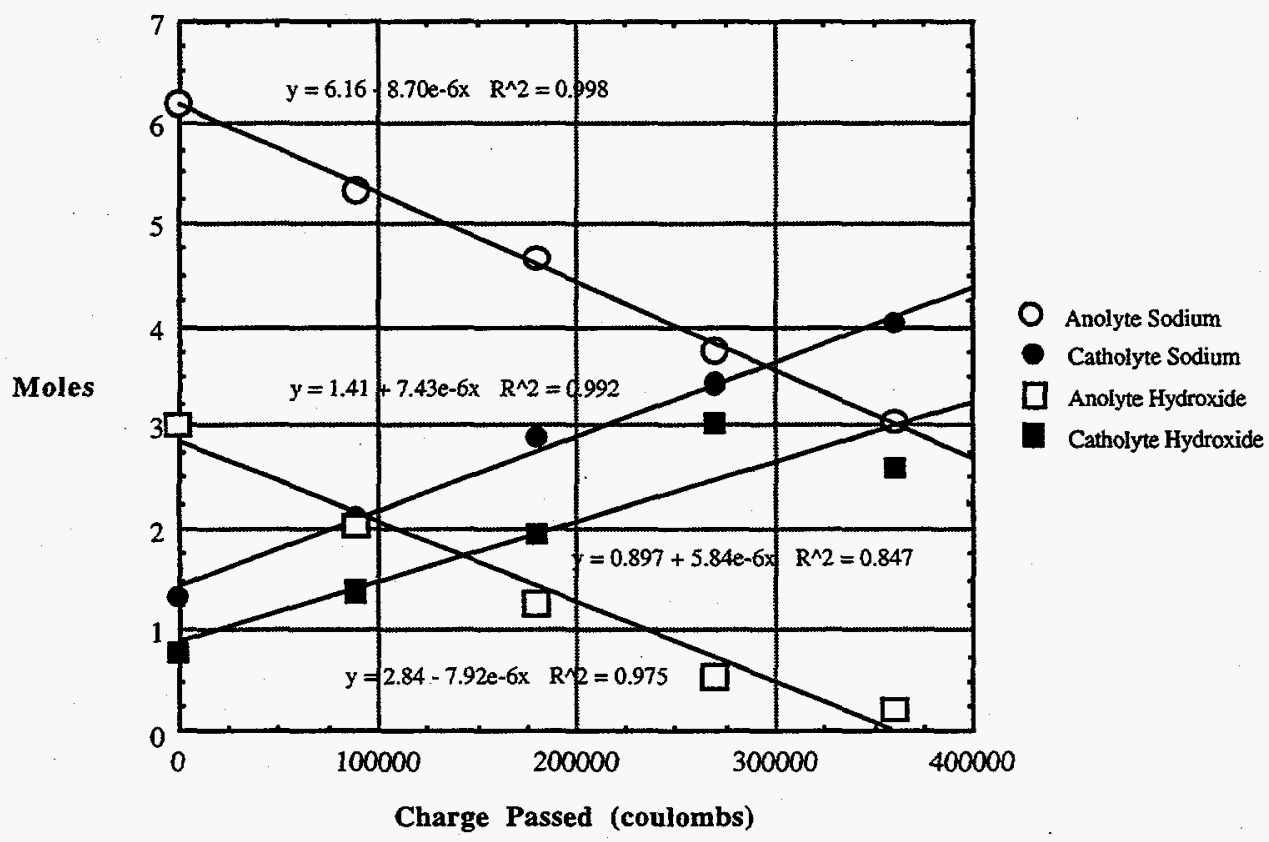

Figure 15. Change in Moles of Sodium and Hydroxide in Catholyte and Anolyte for Test CR14

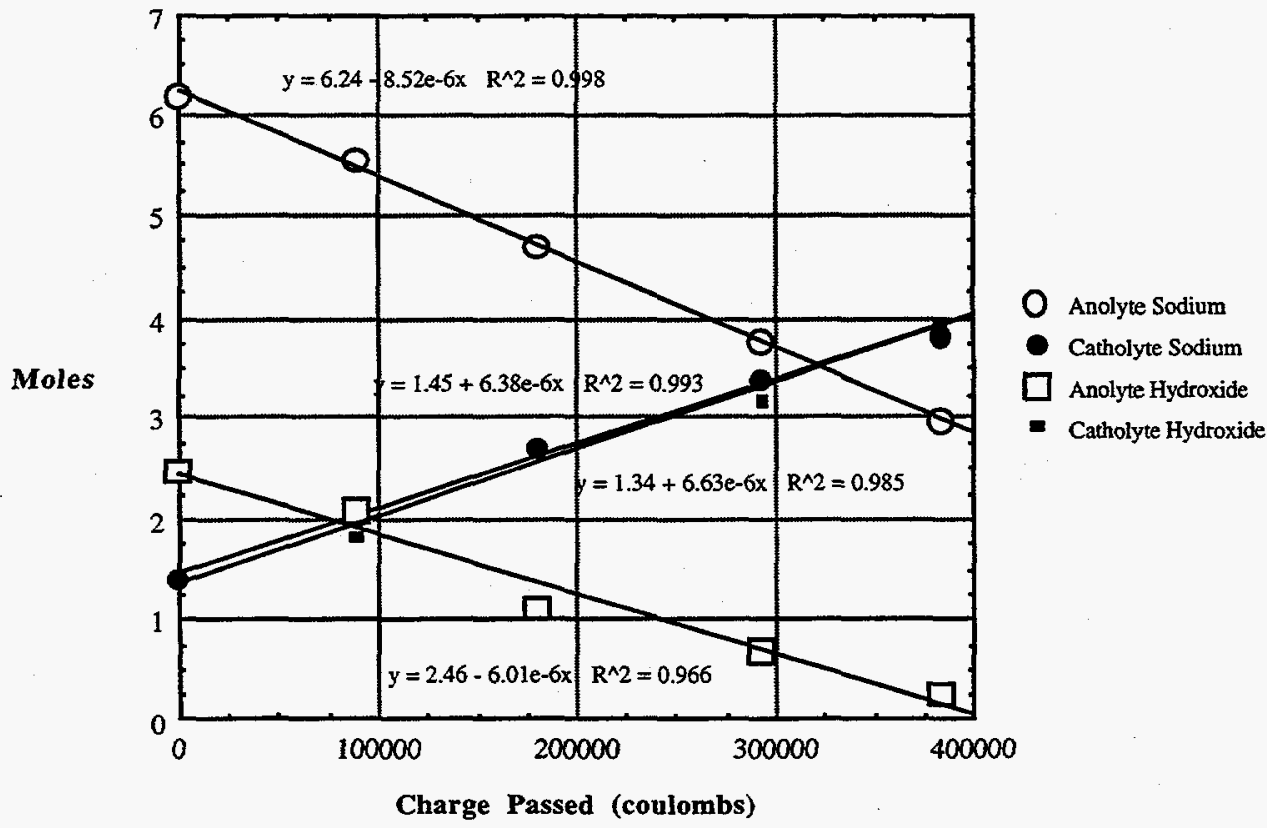




\begin{tabular}{|c|c|c|c|c|c|c|c|c|c|c|c|c|c|c|c|}
\hline Tost ID & $\mathrm{CA}_{3}$ & CA4 & CR5 & CR6 & CA7 & CRB & CR9 & CA10 & CR11 & CR12 & CA13 & CR14 & Average & Std. Dev. & $\%$ RSD \\
\hline Element/Species & $(\mathrm{mole} / \mathrm{C})$ & (mole/C) & (mole/c) & (mole/c) & $(\mathrm{mole} / \mathrm{C})$ & (mole/c) & (mole/C) & $(\mathrm{mole} / \mathrm{C})$ & (mole/C) & $(\mathrm{mole} / \mathrm{C})$ & $(\mathrm{mole} / \mathrm{C})$ & (mole/c) & (mole/c) & (mole/c) & \\
\hline $\mathrm{CO} 3$ & $1.50 E-06$ & bdl & bdl & $4.81 \mathrm{E}-07$ & 2.32E-07 & $1.56 \mathrm{E}-08$ & $2.49 E-08$ & $3.01 E-07$ & $1.08 \mathrm{E}-07$ & 9.81E-08 & $6.62 E-07$ & $1.45 E-08$ & $3.43 E-07$ & 4.59E-07 & 133.76 \\
\hline Al & $1.99 E-09$ & $1.27 E-08$ & $4.31 E-08$ & $3.74 E-08$ & 5.33E-09 & $1.44 \mathrm{E}-09$ & $3.56 \mathrm{E}-08$ & $4.70 E=08$ & 4.44E-09 & 4.36E-09 & 7.31E-09 & 7.53E-09 & 1.74E-08 & $1.77 \mathrm{E}-08$ & 102.28 \\
\hline $\mathrm{Cr}$ & $2.07 E-10$ & $2.32 E \cdot 10$ & $1.66 \mathrm{E}-10$ & $3.67 E-10$ & $5.54 E-10$ & $1.50 \mathrm{E}-10$ & $4.79 E-10$ & $6.98 \mathrm{E}-10$ & $4.61 \mathrm{E}-10$ & $3.02 E-10$ & $1.58 E-10$ & $1.40 E-10$ & $3.26 \mathrm{E}-10$ & $1.85 E-10$ & 56.76 \\
\hline$p$ & 2.43E-09 & $2.72 E-09$ & 2.22E-09 & 4.31E-09 & $6.51 E-09$ & $3.77 E-10$ & $1.21 \mathrm{E}-09$ & 3.51E-09 & 2.32E-09 & 1.27E-09 & 1.46E-09 & $3.52 \mathrm{E}-10$ & 2.39E-09 & $1.75 E-09$ & 73.28 \\
\hline Si & $5.75 \mathrm{E} \cdot 10$ & $6.43 E \cdot 10$ & $4.60 E-10$ & 1.02 E-09 & $2.56 \mathrm{E}-09$ & 1.94E-09 & 6.21E-09 & $9.04 E-09$ & 5.97E.09 & 3.91E.09 & $2.05 E-09$ & 1.81E.09 & $3.02 E .09$ & $2.73 E \cdot 09$ & 90.47. \\
\hline NO3 & $2.80 \mathrm{E}-08$ & $9.18 \mathrm{E} \cdot 09$ & $3.98 \mathrm{E}-09$ & 2.43E-09 & $7.52 E-08$ & $1.88 \mathrm{E}-09$ & bdl & $3.51 E-09$ & bdl & $9.67 E-08$ & bdl & bdl & $2.76 E-08$ & $3.74 E-08$ & 135.59 \\
\hline $\mathrm{NO} 2$ & 4.29E.09 & $8.08 E .09$ & 9.36E-10 & ball & $6.26 \mathrm{E} \cdot 09$ & 1.69E-09 & 6.82E-08 & 1.97E-09 & 1.30E.09 & bdl & boll & ball & $1.16 E-08$ & 2.30E-08 & 198.62 \\
\hline Total NOx & $3.23 E-08$ & $1.73 E-08$ & 4.91E-09 & 2.43E-09 & $8.14 E-08$ & $3.57 \mathrm{E}-09$ & $6.82 \mathrm{E}-08$ & $5.48 \mathrm{E}-09$ & $1.30 E-09$ & 9.67E-08 & ball & boll & $3.14 \mathrm{E}-08$ & $3.68 \mathrm{E}-08$ & 117.47 \\
\hline $\mathrm{SO} 4$ & $2.29 \mathrm{E}-09$ & 3.13E-10 & $2.90 E-10$ & $6.79 E-10$ & bdl & 4.05E-10 & bdI & 1.13E-09 & bdl & $2.70 E-09$ & ball & bdl & $1.12 E-09$ & 9.92E-10 & 88.92 \\
\hline $\mathrm{PO4}$ & 5.53E-10 & $6.18 E-10$ & 4.42E-10 & $9.78 E-10$ & boll & $7.99 \mathrm{E}-10$ & bdl & $9.31 E-10$ & bdi & 1.61E-09 & bal & boll & $8.48 E-10$ & $3.91 \mathrm{E}-10$ & 46.07 \\
\hline$F$ & bdl & bdl & bdl & bdl & bdl & boll & bdl & boll & bal & bd! & bdl & bdl & ball & & \\
\hline $\mathrm{Cl}$ & bol & bdl & bdi & bdl & bdl & bdl & bad! & ball & boll & bdl & bal & bdl & bdl & & \\
\hline & & & & & & & & & & & & & & & \\
\hline \multicolumn{2}{|c|}{ Ratio of Flux to Na Flux } & & & & & & & & & & & & Averago & Sta. Dov. & $\%$ RSD \\
\hline $\cos$ & $9.59 \mathrm{E} \cdot 02$ & & & $2.66 \mathrm{E} \cdot 02$ & $8.71 E .03$ & $.06 E .03$ & $1.06 E-03$ & 1.13E-02 & 5.61E-03 & 5.43E-03 & $5.93 \mathrm{E}-02$ & $1,47 E=03$ & $2.16 E-02$ & $3.16 \mathrm{E}-02$ & 146.13 \\
\hline Al & $1.28 \mathrm{E} \cdot 04$ & $7.76 \mathrm{E}-04$ & $2.58 E-03$ & 2.07E. -03 & 2.01E-04 & $9.83 E-05$ & $1.51 E-03$ & 1.77E. .03 & 2.31E-04 & $2.41 E-04$ & $6.55 \mathrm{E}-04$ & 7.64E-04 & $9.19 \mathrm{E}-04$ & $8.54 \mathrm{E}-04$ & 92.99 \\
\hline $\mathrm{Cr}$ & $1.33 E-05$ & $1.41 \mathrm{E}-05$ & 9.94E-06 & $2.03 E .05$ & $2.08 E-05$ & $1.02 E-05$ & $2.03 E-05$ & $2.63 \mathrm{E}-05$ & $2.40 E-05$ & $1.67 E-05$ & $1.42 E-05$ & $1.42 E-05$ & $1.70 E-05$ & $5.27 E-06$ & 30.97 \\
\hline$p$ & $1.56 \mathrm{E}-04$ & $1.66 \mathrm{E}-04$ & 1.33E-04 & $2.38 E-04$ & $.2 .45 \mathrm{E}-04$ & $2.57 \mathrm{E}-05$ & 5.11E-05 & 1. $.32 E-04$ & 1.21E-04 & 7.01E-05 & $1.31 E-04$ & $3.57 E \cdot 05$ & $1.25 \mathrm{E}-04$ & 7.15E-05 & 57.02 \\
\hline si & $3.68 E .05$ & $3.92 E-05$ & $2.76 \mathrm{E}-05$ & 5.63E-05 & 9.64E-05 & $1.32 \mathrm{E}-04$ & $2.63 E-04$ & $3.41 E-04$ & $3.11 E-04$ & $2.17 E-04$ & 1.83E-04 & $1.84 E-04$ & 1.57E-04 & $1.10 \mathrm{E}-04$ & 69.96 \\
\hline NO3. & $1.80 \mathrm{E} \cdot 03$ & $5.60 \mathrm{E}-04$ & 2.39E-04 & $1.34 E .04$ & 2.83E-03 & $1.28 \mathrm{E} \cdot 04$ & & 1.32E-04 & & 5.35E-03 & & & $1.40 E-03$ & $1.88 \mathrm{E}-03$ & 134.52 \\
\hline NO2 & $2.75 \mathrm{E}-04$ & $4.93 E-04$ & 5.61E-05 & & $2.35 \mathrm{E} \cdot 04$ & $1.15 \mathrm{E}-04$ & $2.89 \mathrm{E}-03$ & 7.42E-05 & $6.78 \mathrm{E}-05$ & & & & 5.26E-04 & $9.67 E-04$ & 183.87 \\
\hline Total NOX & $2.07 E-03$ & 1.05E-03 & $2.95 E-04$ & 1.34E-04 & $3.06 \mathrm{E}-03$ & 2.43E-04 & $2.89 E-03$ & 2.06E-04 & $6.78 \mathrm{E}-05$ & 5.35E-03 & & & $1.54 \mathrm{E}-03$ & $1.77 \mathrm{E}-03$ & 115.41 \\
\hline 504 & $1.47 E-04$ & $1.91 \mathrm{E}-05$ & $1.74 \mathrm{E}-05$ & $3.75 E-05$ & & $2.76 E-05$ & & 4.27E-05 & & 1.49E-04 & & & 6.29E-05 & $5.89 \mathrm{E}-05$ & 93.54 \\
\hline $\mathrm{PO} 4$ & $3.54 \mathrm{E}-0.5$ & $3.77 E-05$ & $2.65 E-05$ & $5.41 E-05$ & & $5.45 \mathrm{E}-05$ & & $3.51 E-05$ & & $8.92 E-05$ & & & $4.75 \mathrm{E}-05$ & $2.11 E-05$ & 44.40 \\
\hline
\end{tabular}


Distribution:

D. W. Geiser, DOE-HQ

P. McGinnis, ORNL

W. C. Laveille, 703-A

D. Kurath, PNNL

W. E. Lawrence, PNNL

W. L. Kuhn, PNNL

R. E. White, University of South Carolina

J. W. Van Zee, University of South Carolina

J. W. Weidner, University of South Carolina

L. M. Papauchado, 773-A

C. R. Wolf, 773-A

W. L. Tamosaitis, 773-A

S. D. Fink, 773-A

S. T. Wach, 773-43A

J. L. Steimke, 786-5A

J. P. Morin, 719-4A

R. W. Brandon, 719-4A

B. L. Lewis, 703-H

J. R. Fowler, 704-Z

T. B. Edwards, 773-42A

D. T. Hobbs, 773-A

IWT-LWP File, 773-A

TIM, 773-52A 